\title{
Die Zeit, die ist ein sonderbar Ding [Time is a strange thing]
}

Having announced my editorship with an editorial whose title was in French (Plus ça change ...) (Ames, 2003), it seems appropriately symmetrical to commemorate my departure ("editor eject" as opposed to "editor elect"?) with a final editorial whose title is drawn from another major European language. The German title serves four functions: it offers homage to the ethnic origins of our incoming German-born Editor-in-Chief (though given the idiomatic excellence of Nicola Lautenschlager's English I suspect it will be the last bit of German seen in these pages for several years), acknowledges the struggle I have had to try and learn something of the German language in formal weekly lessons since April 2006, and, in addition to its relevance to my situation as outgoing editor, it is also a quotation, from Hugo von Hofmannstahl's libretto to Richard Strauss's opera Der Rosenkavalier (translatable as The Knight of the Rose or simply The Rose Bearer) (Strauss and Hofmannsthal, 1910) which is a work that deals, as much as anything, with questions of transition and adjustment.

The fact that I have now completed eight years as editor of International Psychogeriatrics - I started my duties by editing the June 2003 issue (volume 15 , issue 2) and now close them by editing the March 2011 issue $(23,2)$, my 43rd regular issue of the 88 regular issues published since the journal's foundation in 1989, as well as eight supplements on my watch too - a few days before the close of my term of office on 3 January 2011, in addition to an earlier five-and-a-half-year stint as editor of the IPA Bulletin, has caused me to ponder more than usual the passing of time, and by implication death in general and my own in particular, for death is, for everyone, the eventual consequence of the inexorable passage of time. I have been influenced considerably in these thoughts by a 35-year acquaintance with Der Rosenkavalier (an opera in which, after experiencing it 15 times in performance, I continue to find newly revealed beauties, complexities, humor and insights), and a near 40-year intermittent engagement with Giuseppe di Lampedusa's great novel, Il Gattopardo [The Leopard] (di Lampedusa, 1958), also realized in an equally magisterial film by Luchino Visconti which I have seen five times.

One of the four central characters of Strauss's opera is the Feldmarschallin Prinzessin Marie-
Therese Werdenberg (the Marschallin, so called because of her marriage to a much older Field Marshall who never appears in the opera). Set in an anachronistic rose-tinted vision of an eighteenthcentury Vienna that never quite existed, the work concerns not only the arranged marriage of a boor from the countryside, but the relinquishing of her 17 -year-old lover by the Marschallin who is aged about 35. At the piece's core is her great first Act monologue in which she considers how, from being a young girl fresh from the convent pressed into marriage with an older man, she will one day be old herself and referred to as such by passers-by in the street. She wonders not only how God can let this occur, but why on earth she is permitted to realize so clearly what is happening to her. Before her lover returns she comes to the conclusion that the important question is not what will happen, but how to bear it. Then, she speaks to her ardent and uncomprehending paramour about how time flows constantly, evident in the mirror, flowing like sand in the hourglass, and confides that sometimes she gets up in the middle of the night to stop all the clocks in her house, in a vain attempt to halt its progress (the imitation at this point of chimes striking, expressed on the upper strings of two harps is most evocative). And then this Roman Catholic woman, who might today be at risk of a lawsuit for child sexual abuse, and who must, if she thinks of it, regard herself as being in a state of mortal sin, concludes that we should nevertheless be unafraid of time, as it is the creation of the divine being who called us all into existence.

Although the Marschallin is far from being a perfect individual, she does show an eminently good understanding of the key principles of aged care, visiting her frail uncle Griefenklau (Griffinclaw) because the old man likes to see her, and finally, via the medium of a ravishing trio for three soprano voices, facilitating the engagement of her lover to the 15-year-old daughter of a nouveau riche businessman with whom he has fallen suddenly in love.

Although it is never made explicit, the opera is really about transition and death, and the fact that it was first performed just three and a half years before an entire tradition of European civilization (the musico-dramatic element of which Der Rosenkavalier could be said to form the apogee) 
was consumed in the charnel house of destruction unleashed in 1914, gives it added poignancy. The opera is a summation and conclusion of a vanished cultural lineage. Like all great art, Der Rosenkavalier has the potential to move us to the depths of our souls.

In contrast to the bitter sweet nostalgia of Der Rosenkavalier, Il Gattopardo (which I must still read in English translation from the original Italian) is a baroque meditation on mortality and death. Its (anti-?) hero is another middle-aged aristocrat, the 50-year-old Don Fabrizio, Prince of Salina, living through the turmoil of the early 1860 s as the Sicilian monarchy collapses in the face of Garibaldi's challenge, and the island becomes a never-to-be-integrated component of a unified Italy. Exhausted by his contemplation of 25 centuries of Sicilian history, Don Fabrizio considers that the only thing worth hating is eternity and that one should feel nothing but compassion for our fellow ephemeral beings engaged in the brief process of enjoying "the tiny ray of light granted them between two shades, before the cradle, after the last spasms." When his own turn comes to die, at the age of 73 , he tots up the balance sheet of his life in his mind, "trying to sort out of the immense ash-heap of liabilities the golden flecks of happy moments", and concludes "in all I may have lived, really lived, a total of two (years) ... three at the most".

Perhaps one lesson to be learned from di Lampedusa's requiem for a lost world, written while he himself was being consumed by the cancer that would kill him, in melancholy recollection of a society that was destroyed at last by the culmination in 1945 of that cataclysm initiated in 1914, as the military railway timetables of Germany, Austria, Russia and France catapulted the world towards a catastrophe 31 years in its complete unfolding, is that, like the Marschallin, we should give more thought to the how and less to the what, and that our lives will be better and happier if we concentrate more on beauty, truth and goodness and less on the incessant press of mundane demands, activities and expectations.

I am pleased to say that when I look back, the time I have spent editing this journal will count among my golden flecks of happy moments! I have been privileged to work with superb colleagues. It might be invidious to single some out for particular praise, but nevertheless I will do so. In 2003 Conrad Guettler enticed us to publish with Cambridge University Press and the decision to do so has never been regretted. Gavin Swanson and Jamie Hutchins have been splendid journal managers, always willing to respond to the most banal of queries, constantly thinking of how things could be improved. Gwenda Edwards and Sue Tuck were, in their very different ways, exemplars of effective and helpful production editing and key figures in ensuring that the journal appeared on time. Our copyeditors, Judith Sylph (previously Robin Eastwood's editorial assistant), Gill Mautner and more recently Anne DunbarNobes have dealt promptly and accurately with papers that varied from the well laid out and idiomatically written to the less well organized and idiosyncratically phrased. John O'Brien and later Nicola Lautenschlager too were diligent deputies, committed to the journal's development, while in Marilyn Kemp I have had the best editorial assistant any editor could wish to meet. I could not have edited the journal without constant support and advice from my excellent and evolving editorial panel, but John Chibnall, our statistical advisor, stood out like a beacon; his accurate and acute reports on papers have caused many marginal submissions to develop into concise and useful contributions to our discipline. A succession of International Psychogeriatric Association (IPA) presidents, executive officers and members of the IPA board of directors has been consistently encouraging and supportive, while both my executive editors, Fern Finkel and Susan Oster, have been towers of strength. Ed Chiu, Michael Davison and Leonardo Pantoni did all they could as chairmen of IPA's publication committee to help me in my editorial role. Our contributors have more than doubled the journal's impact factor in only eight years, while the support of our readers has been the rock upon which the whole edifice has been erected. Finally I should acknowledge my predecessors, who left me much more than a foundation upon which to continue building, especially Robin Eastwood, who did so much to bring the journal up to a high standard, and gave me a break as both book review editor and then as deputy editor, which then gave me the inside running when I came to apply for the editor's job. My ultimate satisfaction lies in the circumstances of the latest editorial transition. In Nicola Lautenschlager International Psychogeriatrics has a new editor of the highest calibre, an academic old age psychiatrist with impeccable credentials and an enviable work ethic. I wish her every success and look forward to observing the rise and rise of International Psychogeriatrics as I "Unburthen'd crawl towards death" (King Lear, I, i, 41) though I hope to do so very slowly indeed!

I have indulged myself a little in assembling the contents of this final issue from among papers pre-published at the FirstView section of the journal's website. I have tried to give preference to papers by close friends and colleagues, especially those from the antipodes, and have included a case report (Huntley et al., 2011) which is based 
on a case presentation that I had the privilege to chair at the Institute of Psychiatry in late 2009. Although my deputy and associate editors did, against the odds, prevent me from turning International Psychogeriatrics into Opera magazine during my editorship, I am pleased to close my term of office by observing that no less prominent a figure than Cosima Wagner, Franz Liszt's daughter and Richard Wagner's second wife, was tormented by auditory hallucinations of brass bands in the last 20 years of her life against the background of a series of Stokes-Adams attacks (Hilmes, 1980). This is not the place to debate whether the prejudiced old battle-axe actually deserved such tortures, but it does illustrate yet another connection between the worlds of opera and old age psychiatry!

\section{Conflict of interest declaration}

David Ames was a foundation member of the (now defunct) Richard Strauss Society of Great Britain and is a member of two Wagner societies.

\section{Acknowledgments}

I thank Marlies Herrmann-Pichler for assisting with advice about translation into English of elements of the original German libretto of der Rosenkavalier, Michael Collins Persse for starting the process of convincing me that $I l$ Gattopardo is, as L. P. Hartley thought, perhaps the greatest novel of the twentieth century, and the late Cynthia Stallman-Patacci for inspiring me when teaching the subject "Sicily Greek, Roman and Byzantine" at the University of Melbourne in 1991. A paper incorporating some elements of this editorial was presented by the author at the Second International Arts and Health Conference in Melbourne on 18 November 2010.

\section{DAVID AMES}

Former editor International Psychogeriatrics

Melbourne, Australia

Email: dames@unimelb.edu.au

\section{References}

Ames, D. (2003). Plus ça change ... International Psychogeriatrics, 15, 107-110.

di Lampedusa, G. (1958). Il Gattopardo. Milan: Feltrinelli Editore.

Hilmes, O. (2010). Cosima Wagner: Lady of Bayreuth, translated by S. Spencer. Yale: Yale University Press.

Huntley, J. D., Sandall, A. and Philpot, M. (2010). "In the midnight hour": a case report of musical hallucinations with multiple etiological factors treated with lamotrigine. International Psychogeriatrics, 23, 322-324. doi:10:1017/S1041610200019997

Strauss, R. and von Hofmannsthal, H. (1910). Der Rosenkavalier. Berlin: Adolph Fürstner. 